\title{
DNA substrate specificity of pea DNA methylase
}

\author{
Claire E. HOULSTON, Heather LINDSAY, Sriharsa PRADHAN and Roger L. P. ADAMS* \\ Plant Molecular Sciences Group, Department of Biochemistry, University of Glasgow, Glasgow G12 8QQ, U.K.
}

DNA methylase, present in low-salt extracts of nuclei prepared from Pisum sativum shoot tips, methylates model DNA substrates containing CNG trinucleotides or CI dinucleotides only. The binding to the hemimethylated trinucleotide substrates is very much stronger and more persistent than the binding to the unmethylated substrates or to the hemimethylated dinucleotide substrate. When the DNA concentration is limiting, the rate of methyl-group transfer with the hemimethylated CNG substrate is much greater than that with the unmethylated CNG. However, the $V_{\max }$ is similar for the two CNG substrates. On fractionation using Q-Sepharose, two peaks of activity are seen with different relative activities using the di- and trinucleotide substrates. The relative activity with these substrates changes during purification, during plant growth and on heating at $35^{\circ} \mathrm{C}$ as well, indicating that more than one enzyme or more than one form of the enzyme may be present.

\section{INTRODUCTION}

The DNA of plants contains methylcytosine both in $\mathrm{mCG}$ dinucleotides and in $\mathrm{mCNG}$ trinucleotides (Gruenbaum et al., 1981) and this explains in part how the proportion of cytosines that are methylated can be as high as $30 \%$ in plants (Adams and Burdon, 1985). $M$ is used to represent 5-methylcytosine in oligonucleotides. In peas (Pisum sativum) we have shown, using h.p.l.c. analysis of acid-hydrolysed DNA, that $5 \%$ of the bases (26\% of the cytosines) are methylcytosine (Yesufu et al., 1991).

The function of this high level of methylcytosine in plant DNA is unknown. It has been difficult to determine the function of the much lower levels of methylcytosine found in the DNA of vertebrates, but it is now becoming clear that this can bring about gene silencing in at least two different ways (Meehan et al., 1989; Adams, 1990; Lewis et al., 1992). Firstly, methylation of certain promoters can interfere with the binding of transcription factors (Dobrzanski et al., 1988; Watt and Molloy, 1988; IguchiAriga and Schaffner, 1989; Comb and Goodman, 1990). An alternative, though less specific, mechanism involves the interaction of a methylcytosine-binding protein with a group of methylcytosines, which leads to the incorporation of the methylated region of the DNA into a form of inactive chromatin (Boyes and Bird, 1991; Meehan et al. 1989). Although there are several reports (e.g., Banks and Federoff, 1989; Matzke and Matzke, 1990; Weber et al., 1990) of DNA methylation interfering with plant gene expression, little information is available about which of the above mechanisms operates. However, there is no reason to doubt that both operate, and methylcytosinebinding proteins have been detected in plants (Zhang et al., 1989). Nevertheless, with the increased frequency of occurrence of methylcytosine in plant DNA, clusters of methylcytosine will occur far more frequently than in animal DNA and details of the 'inactive chromatin' mechanism may differ between plants and animals.

Methylation of CG dinucleotides alone in plant DNA has been shown by Hershkovitz et al. (1990) to be effective in gene silencing and they suggested that the presence of methylcytosine in MNG sequences may serve some entirely different function. If this were so, then it is likely that the mechanism and control of the methylation of CG dinucleotides and of CNG trinucleotides would be different. This would be facilitated if the two target sequences were recognized by different enzymes.

We have partially purified a DNA methylase from the nuclei of pea-shoot tips (Yesufu et al., 1991). We present evidence now that two species of enzyme might be present, although complete fractionation has not been achieved. Using nearest-neighbour analysis, we have reported previously results consistent with the transfer of methyl groups both to CG dinucleotides and to CNG trinucleotides. The present paper extends this work using synthetic DNA substrates that contain only CG (or CI) dinucleotides or only CNG trinucleotides. On fractionation using Q-Sepharose, methylase activity measured using substrate containing the dinucleotide target sequence fails to coincide with activity measured using the trinucleotide target sequence and the ratio of the activity with the different substrates varies under a variety of conditions. Furthermore, investigation of the interaction of the enzyme with unmethylated and with hemimethylated substrates leads us to propose that the enzyme(s) might interact in a fundamentally different way when carrying out maintenance methylation of CNG sequences.

\section{EXPERIMENTAL}

\section{Isolation and assay of DNA methylase}

Peas (Pisum sativum var. Feltham First) were obtained from Booker Seeds, Sleaford, Lincs., U.K. Nuclei from 5-7-day-old pea-shoot tips were prepared as previously described (Yesufu et al., 1991) and were extracted with buffer $\mathrm{M}[50 \mathrm{mM}$ Mops/NaOH buffer, $\mathrm{pH} 7.2 ; 1 \mathrm{mM}$ EDTA; $0.01 \mathrm{NaN}_{3} ; 1 \mathrm{mM}$ dithiothreitol; $60 \mu \mathrm{g} / \mathrm{ml}$ phenylmethanesulphonyl fluoride; $10 \%$ (w/v) glycerol] containing $0.2 \mathrm{M} \mathrm{NaCl}$, to give the crude salt extract (E1) that was used in most of the experiments described here. For storage or direct use, E1 was dialysed overnight against buffer $\mathbf{M}$ containing $50 \%(\mathrm{w} / \mathrm{v})$ glycerol. This gave an enzyme preparation with $0.2-0.5 \mathrm{mg}$ of protein $/ \mathrm{ml}$ that could be stored at $-20^{\circ} \mathrm{C}$ for several weeks with little loss in activity. The assay for methylase activity was as previously described (Yesufu et al., 1991) except that different DNA substrates were used, as indicated in the text. In outline, the assay involved a $2 \mathrm{~h}$ incubation at $30^{\circ} \mathrm{C}$ with tritiated $S$-adenosylmethionine, followed by the isolation of the radioactive DNA product for counting. The incubation con- 
tained BSA ( $5 \mu \mathrm{l}$ of a $10 \mathrm{mg} / \mathrm{ml}$ solution); El ( $5 \mu \mathrm{g}$ of protein); DNA $(5 \mu \mathrm{l}) ; S$-[ methyl $\left.^{3} \mathrm{H}\right]$ adenosylmethionine $(10 \mu \mathrm{l}$, containing $1.1 \mu \mathrm{Ci}$ at $4.64 \mathrm{Ci} / \mathrm{mmol}$; Amersham International) and buffer $\mathrm{M}$ (to $70 \mu \mathrm{l}$ ).

\section{Chromatography}

E1 (undialysed) was stirred with heparin-Sepharose and either was batch-eluted with buffer containing $0.6 \mathrm{M} \mathrm{NaCl}$ or was eluted from a small column using a $0.2-0.6 \mathrm{M} \mathrm{NaCl}$ gradient. Active fractions were diluted to $0.15 \mathrm{M} \mathrm{NaCl}$ and were stirred with $2 \mathrm{ml}$ of Q-Sepharose (Pharmacia). The pelleted Q-Sepharose was resuspended and placed in a minicolumn, which was eluted with a $0.15 \mathrm{M}-0.5 \mathrm{M} \mathrm{NaCl}$ gradient (in buffer M). Samples were dialysed overnight against buffer $M$ containing $50 \%(w / v)$ glycerol, before assaying.

\section{Oligonucleotide synthesis and annealing}

Poly $(\mathrm{dI}-\mathrm{dC}) \cdot \operatorname{poly}(\mathrm{dI}-\mathrm{dC})$ was obtained from Sigma Chemical Co. The material used initially had a size range of 100-500 bp, but a more recent batch was mostly longer than $2000 \mathrm{bp}$. Oligonucleotides were synthesized using an Applied Biosystems machine. Except for the alternating $\mathrm{mCG}$ oligonucleotide (which was a hexamer), all the synthetic oligonucleotides were 21-mers. The phosphoramidite derivatives were obtained from British Drug Houses, with the exception of the methylcytosine derivative, which was obtained from Glen Research Corp. Herndon, VA, U.S.A. After deprotection and precipitation, the oligonucleotides were redissolved in annealing buffer (Kadonaga and Tjian, 1986; Tris/HCl, $67 \mathrm{mM}, \mathrm{pH} \mathrm{7.6;} \mathrm{MgCl}_{2}, 13 \mathrm{mM}$; dithiothreitol, 6.7 $\mathrm{mM}$; spermidine, $1.3 \mathrm{mM}$ and EDTA, $1.3 \mathrm{mM}$ ) and, when required, were mixed in equivalent amounts for annealing. This was done by heating the mixture at $88^{\circ} \mathrm{C}$ for $2 \mathrm{~min}, 65^{\circ} \mathrm{C}$ for $5 \mathrm{~min}, 37^{\circ} \mathrm{C}$ for $5 \mathrm{~min}$ and at room temperature for $5 \mathrm{~min}$ before storing at $-20^{\circ} \mathrm{C}$. When using the oligonucleotide containing alternating $\mathrm{mCG}$ residues, the above annealing procedure was preceded by heating the mixture at $100^{\circ} \mathrm{C}$ for $2 \mathrm{~min}$. As indicated in the Results section, the hemimethylated molecules containing the dinucleotide target sequences were inactive as substrates for the pea DNA methylase. A substrate was therefore made using Escherichia coli DNA polymerase (Klenow fragment), using the method of Giordano et al. (1991), except that dithiothreitol $(1 \mathrm{mM})$ was present in the incubation. This product is of high molecular size (500-2000 bp, as judged by electrophoresis) and, as the cytosines and methylcytosines are incorporated at random from a 3:1 mix, it will contain, for every doubly methylated dinucleotide pair, six hemimethylated and nine unmethylated target sites.

\section{RESULTS}

\section{DNA substrate requirements}

Table 1 presents the results of an initial experiment to investigate the substrate requirements of the pea DNA methylase. The single-stranded 21 -mer $(\mathrm{CAG})_{7}$ is a very poor substrate, confirming earlier results (Yesufu et al., 1991) that showed the pea DNA methylase to prefer a double-stranded substrate. Moreover, the single-stranded DNA interferes strongly with the methylation of duplex DNA when both are present in the same incubation [e.g. $0.25 \mu \mathrm{g}$ each of $(\mathrm{CAG})_{7}$ and of $(\mathrm{CAG} \cdot \mathrm{MTG})_{7}$ present together in an incubation gave only $27 \%$ of the activity obtained when the hemimethylated substrate is present alone]. It is probable that this indicates that the enzyme interacts strongly with the single-stranded DNA even though it methylates it very poorly, although an alternative explanation could be that the single strand binds to the hemimethylated duplex to form a triple-stranded structure that is not recognized by the enzyme (Hélène and Toulmé, 1990).

For the animal enzyme poly $(\mathrm{dI}-\mathrm{dC}) \cdot \operatorname{poly}(\mathrm{dI}-\mathrm{dC})$ is an excellent substrate for de novo methylation (Pfeifer and Drahovsky, 1986) and it is used satisfactorily by the pea enzyme. Its high ability to accept methyl groups using the vertebrate enzyme is attributed to its high concentration of target sites, coupled with a much greater ease of denaturation compared with the alternating, CGcontaining substrate. However, the hemimethylated dinucleotide target sequences $\left[\right.$ poly $(\mathrm{CI}) /(\mathrm{MG})_{3}$ and poly $(\mathrm{CI}) /(\mathrm{MI})_{7}$; see Table 1], made by annealing oligonucleotides to poly(dI-dC) poly(dI$\mathrm{dC}$ ), are poor acceptors of methyl groups using the pea enzyme. The accepting strands of the latter contain alternating CI residues, while the 'template' strands contain either alternating mCG or $\mathrm{mCI}$ residues. Although these structures fulfil the requirements of the vertebrate DNA methylase, as defined by Smith et al. (1991), it is possible that the high concentration of methylcytosines renders the duplex resistant to the partial denaturation that appears to be a prerequisite for enzyme interaction (Adams et al., 1979). An alternative possibility is that the presence of the methyl group in an alternating sequence causes the DNA to assume a left-handed helical (Z) conformation (Van Lier et al., 1983), in which form it is less able to accept methyl groups (Vardimon and Rich, 1984). These substrates do not appear to bind with the enzyme, since they do not interfere with the methylation of the hemimethylated trinucleotide target sequence in mixing experiments. (It should be noted that these substrates are methylated by the mouse DNA methylase, showing that they are not incapable of accepting methyl groups; H. Lindsay and R. L. P. Adams, unpublished work.) However, the hemimethylated dinucleotide target sequence $\left[(\mathrm{CI} / \mathrm{MI})_{n}\right.$ in Table 1] prepared by polymerase action is a good substrate for the enzyme and it must be supposed that in this substrate the chance of having long runs of alternating MI dinucleotides is very small.

Pea DNA, which will contain a mixture of unmethylated and hemimethylated di- and trinucleotide target sequences, is quite a good substrate, but the best substrate for the pea enzyme is the oligonucleotide duplex containing the trinucleotide target sequence, especially in the hemimethylated state.

\section{Table 1 Effectiveness of various substrates for pea DNA methylase}

The production of the DNA substrates is described in the Experimental section. $1 \mu \mathrm{g}$ of DNA was incubated with $5 \mu \mathrm{g}$ of DNA methylase protein (fraction E1) for $2 \mathrm{~h}$ at $30^{\circ} \mathrm{C}$ in a reaction volume of $70 \mu \mathrm{l}$ containing $S$. $\left[\right.$ methyl $\left.{ }^{3} \mathrm{H}\right]$ adenosylmethionine and the incorporation of radioactivity into DNA was measured. (CI/MI) ${ }_{n}$ is the substrate prepared using DNA polymerase, whereas $(\mathrm{Cl} / \mathrm{MG})_{3}$ and $(\mathrm{Ct} / \mathrm{MI})_{7}$ were prepared by annealing synthetic oligonucleotides to (poly $\mathrm{dl}-\mathrm{dC}$ ) $($ poly $\mathrm{dl}-\mathrm{dC})$. The values are averages of duplicate determinations. Individual assays have been repeated several times.

\begin{tabular}{lc}
\hline $\begin{array}{l}\text { Substrate } \\
(1 \mu g \text { per assay of } 70 \mu \mathrm{l})\end{array}$ & $\begin{array}{l}\text { Methylase activity } \\
\text { (c.p.m./2 } \mathrm{h} \text { per } 5 \mu \mathrm{g} \text { of protein) }\end{array}$ \\
\hline None & 30 \\
Pea DNA & 690 \\
$(\mathrm{CAG})_{7}$ & 30 \\
$(\mathrm{CAG} / \mathrm{CTG})_{7}$ & 1210 \\
$\left(\mathrm{CAG} / \mathrm{MTG}{ }_{7}\right.$ & 3230 \\
$(\mathrm{Cl} / \mathrm{Cl})_{n}$ & 420 \\
$(\mathrm{Cl} / \mathrm{MG})_{3}$ & 120 \\
$(\mathrm{Cl} / \mathrm{MI})_{7}$ & 60 \\
$(\mathrm{Cl} / \mathrm{MI})_{n}$ & 820
\end{tabular}


(a)

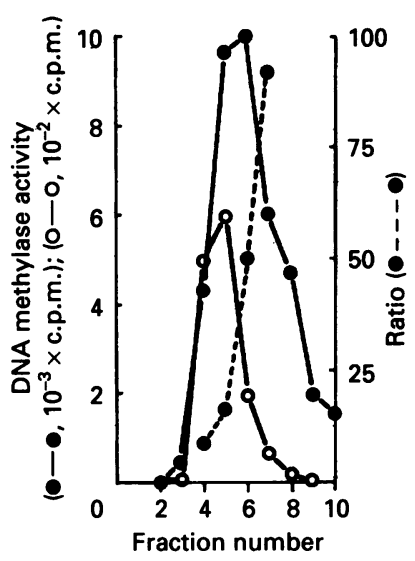

(b)

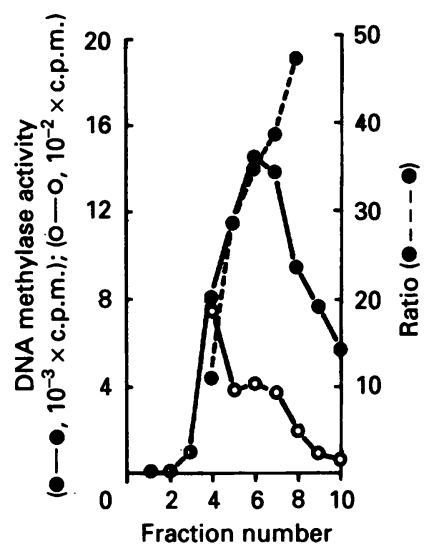

Figure 1 Fractionation of pea DNA methylase on Q-Sepharose

Nuclear extract (E1) was treated with heparin-Sepharose and then was applied to a $Q$ Sepharose column, as described in the Experimental section. Activity was assayed either with $($ poly $d l-d C) \cdot($ poly $d l-d C)(O)$ or with $d(C A G / M T G)_{7}(O)$. The dotted line indicates the ratio of activity for the two substrates. The results of two fractionations are shown as (a) and (b).

\section{Enzyme fractionation}

During purification we have assayed enzymic activity using either (poly dI-dC) $\cdot($ poly dI-dC) or the double-stranded substrate made by annealing $(\mathrm{CAG})_{7}$ with $(\mathrm{mCTG})_{7}$ (that is, the hemimethylated trinucleotide target sequence). These two substrates allow us to follow CG and CNG methylation and, additionally, allow a comparison of de novo and maintenance methylation. When a nuclear extract is fractionated by gel filtration on Superose 6, the enzymic activity measured with the two substrates co-elutes (results not shown), which is consistent with the presence of only one enzyme species capable of de novo and maintenance methylation of di- and trinucleotide target sequences. In contrast, Figure 1 shows two examples of the elution from Q-Sepharose of enzyme that had been previously purified by affinity chromatography on heparin-Sepharose. The peak activity with the two substrates does not coincide and the relative activity with the hemimethylated trinucleotide target DNA increases steadily across the column. There is, in fact, evidence for two or more different enzyme species.

We have evidence from SDS/PAGE that there is a different degree of degradation in different preparations, although we have not been able to prevent this routinely. In some preparations, fraction 4 from the Q-Sepharose column shows one predominant protein of $160-180 \mathrm{kDa}$, with smaller proteins present in later fractions. Similar preparations containing a predominant high-molecular-mass protein were described by Yesufu et al. (1991). Other preparations show the presence of more bands of a range of sizes. Figure 2 shows examples from two preparations in which the proteins were stained or Western blotted onto Hybond C-extra (Amersham) and were probed using an antibody either raised to a peptide present in the presumed active site of the mouse DNA methyltransferase (Ab156; Figure 2a) or to a $55 \mathrm{kDa}$ protein present in the wheat DNA methyltransferase (Figure 2b; this antibody was kindly provided by $\mathrm{H}$. Follmann of Gesamthochschule Kassel Universität). The purified enzyme and the Western blots show evidence of several bands that we believe to be the enzyme and its breakdown products. There is a cluster of high-molecular-
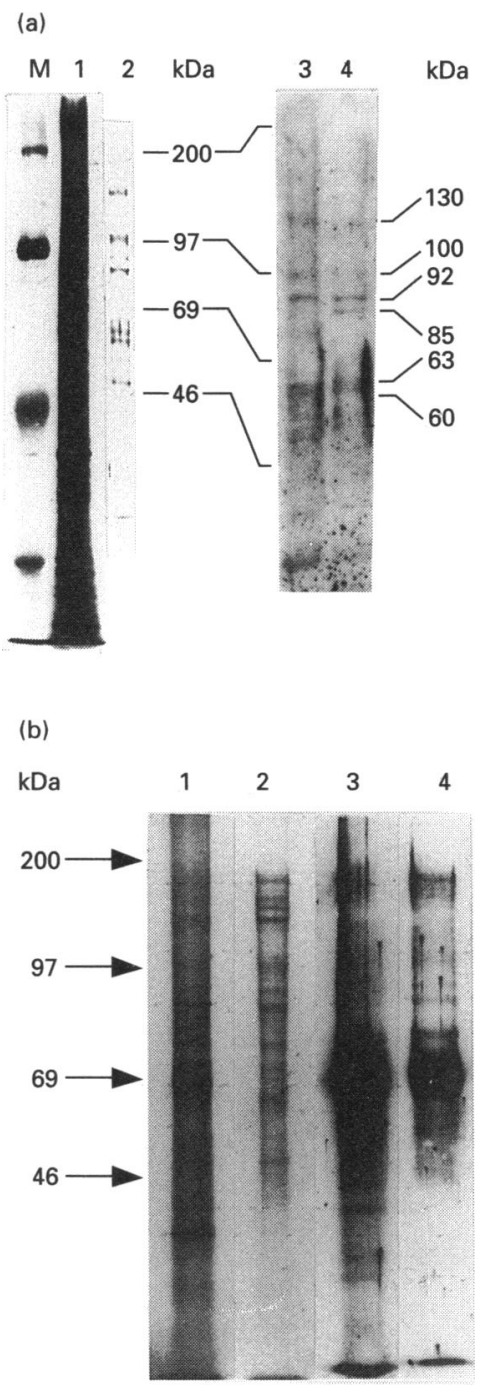

\section{Figure 2 Size fractionation and cross-reactivity of pea DNA methylase}

Nuclear extract (E1) was electrophoresed in lanes 1 and 3 of an SDS/PAGE gel (a and $\mathbf{b}$ ). Lanes 2 and 4 contained pooled fractions (a) or fraction 5 (b) from the Q-Sepharose fractionation. After electrophoresis, the gel either was silver-stained (lanes 1 and 2) or was transferred to Hybond C-extra (Amersham) and probed with an antibody to an active-site peptide in mouse DNA methyltransferase (a; lanes 3 and 4 ) or with an antibody to the wheat DNA methyltransferase 55-kDa protein (b; lanes 3 and 4). Probing was done using enhanced chemiluminescence (Amersham). Molecular-mass markers are shown in lane $M$ and molecular masses are given in $\mathrm{kDa}$.

mass proteins reminiscent of the pattern obtained with the mouse enzyme (Adams et al., 1989). Two proteins of 92 and $85 \mathrm{kDa}$ are highlighted by both antisera, as is a fainter $100 \mathrm{kDa}$ band. A protein of around $70 \mathrm{kDa}$ reacts strongly with the wheat DNA methyltransferase antibody, but not with the antibody to the mouse enzyme active-site peptide. Two smaller proteins of 60 and $63 \mathrm{kDa}$ react with the anti-mouse antiserum, but it cannot be ascertained whether they react with the anti-wheat antiserum because of the strong reaction of this antiserum with the $70 \mathrm{kDa}$ band.

\section{Enzyme stability}

The nuclei used in the purification were obtained from pea shoots 5-7 days after imbibition. As shown previously and 


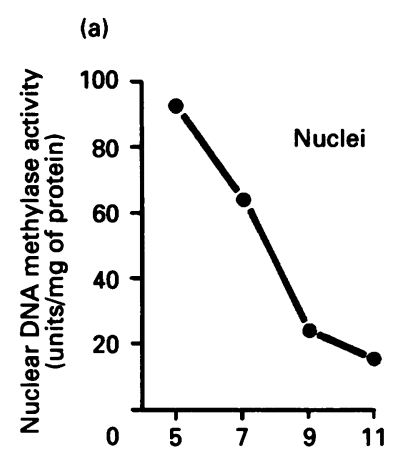

(b)

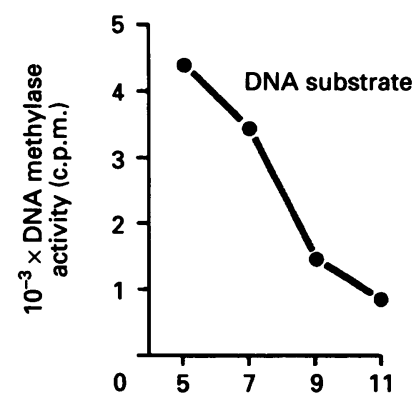

(c)

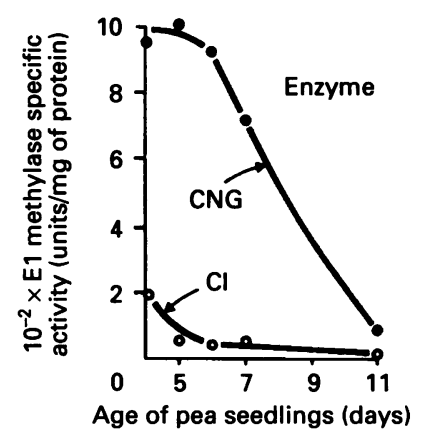

\section{Figure 3 Developmental regulation of methylase}

(a) Nuclei, isolated from pea-shoot tips of the indicated ages, were assayed for methylase activity using their endogenous DNA. (b) DNA, isolated from pea-shoot tips of the indicated ages, was used as a substrate for E1 DNA methylase. (c) E1, isolated from pea-shoot tips of the indicated ages, was used to methylate either (poly $d l-d C) \cdot($ poly $d l-d C)(O)$ or $\mathrm{d}(\mathrm{CAG} / \mathrm{MTG})_{7}$ (O).

confirmed in Figure 3(a), such nuclei show the maximum incorporation of methyl groups into their endogenous DNA. Figure 3(b) indicates that DNA isolated from young shoots is a better acceptor of methyl groups than is DNA isolated from older shoots; that is, such DNA has a greater concentration of acceptor sites, and this alone might explain the higher activity found in nuclei (Figure 3a). However, when fraction E1 isolated from shoots of different ages was used to methylate the synthetic substrates, it was clear that the activity with the hemimethylated trinucleotide target sequence begins to fall after day 5 (Figure 3c). Thus in pea nuclei both the enzyme activity and the ability of the endogenous DNA to accept methyl groups decrease dramatically with age. The enzymic activity with (poly dI$\mathrm{dC}) \cdot($ poly $\mathrm{dI}-\mathrm{dC}$ ) as the substrate behaves somewhat differently, falling sharply between 4 and 5 days and thereafter falling more slowly. On day 4 , activity with the hemimethylated CNG

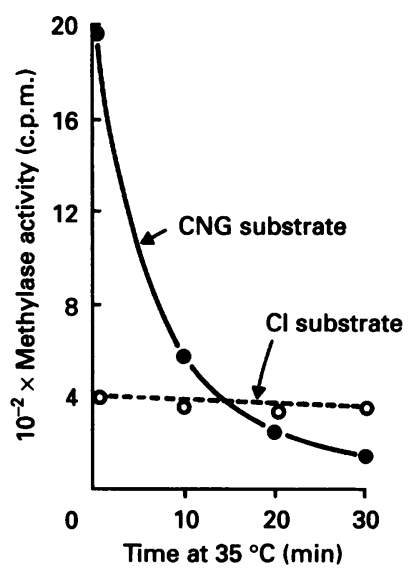

Figure 4 Effect of heating on methylase activity

E1 was incubated at $35^{\circ} \mathrm{C}$ for the indicated times and then incubated in a methylase assay with either (poly dl-dC) $\cdot($ poly $\mathrm{dl}-\mathrm{dC})(\mathrm{O})$ or $\mathrm{d}(\mathrm{CAG} / \mathrm{MTG})_{7}(O)$ as the substrate.

substrate is only about 5 -fold that with (poly dI-dC) $\cdot($ poly dI$\mathrm{dC}$ ), whereas on days 6 and 7 the ratio of activities is 14-20. These values form a range typical of those found with different preparations of E1, though more purified fractions typically show ratios of up to 50 (see Figure 1).

Another situation in which the ratio of the activities with the two substrates changes dramatically is on heating (Figure 4). When either E1 or pooled fractions from the Q-Sepharose column are heated at $35^{\circ} \mathrm{C}$ in the absence of DNA, before incubation at $30^{\circ} \mathrm{C}$, there is a rapid loss in activity measured using the hemimethylated trinucleotide target sequence. We have also shown that activity with the hemimethylated trinucleotide target sequence is more susceptible to digestion with trypsin (results not shown) and hence the loss of activity on heating may be the result of inactivation by proteolysis. Inactivation does not, however, occur on prolonged incubation during assay at $30^{\circ} \mathrm{C}$ (Yesufu et al., 1991 and Figure 5), implying that the enzyme might be stabilized by some component in the assay mixture. This is confirmed by the results shown in Table 2, which show that when the enzyme is pre-incubated at $35^{\circ} \mathrm{C}$ in the presence of both substrates there is only a $14 \%$ loss of activity, as opposed to a $68 \%$ loss when the enzyme is pre-incubated alone. It would appear that some conformational change occurs at $35^{\circ} \mathrm{C}$ that readily leads to a reduction in activity with the hemimethylated trinucleotide target sequence, but that this change is blocked in the presence of substrate. The almost complete protection obtained implies that nearly all the enzyme is associated with substrate.

\section{DNA concentration curves}

Figure 6 shows the effect of varying DNA concentration on enzyme activity using the unmethylated and hemimethylated substrates with the di- or trinucleotide recognition sequences.

The pea DNA methylase is saturated at very low concentrations of the hemimethylated trinucleotide target substrates, but much higher concentrations of the corresponding unmethylated substrates are required for saturation. Nevertheless, at saturating amounts, the rate of methylation of the unmethylated and hemimethylated trinucleotide substrates is similar and is significantly greater than with dinucleotide target sequences or with pea DNA (Table 3). Similar experiments with 
(a)

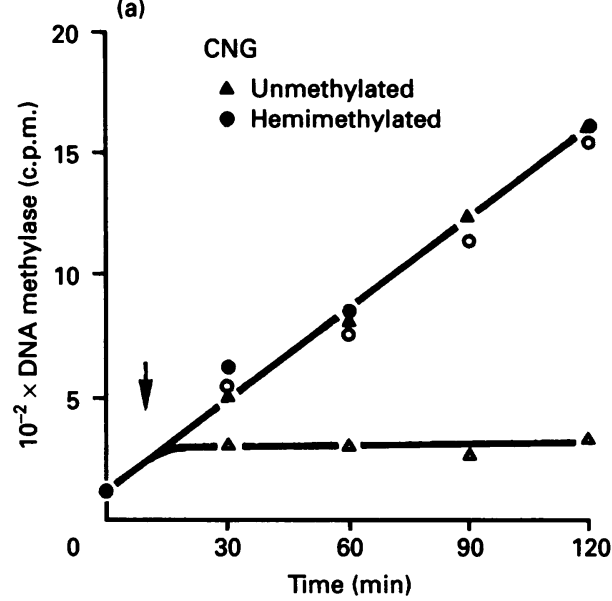

(b)

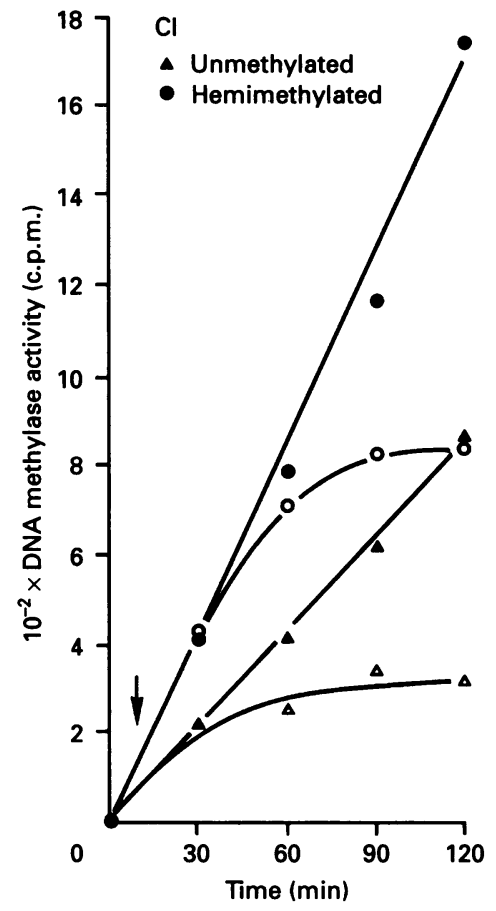

Figure 5 Time course of methylation and the effect of $\mathrm{NaCl}$ added at $10 \mathrm{~min}$

The time course of the reaction is shown for an excess of (a) the trinucleotide target sequences and (b) the dinucleotide target sequences. Triangles represent the unmethylated sequences and circles the hemimethylated sequences. Open symbols show the results when $\mathrm{NaCl}(0.1 \mathrm{M})$ was added to the incubation after $10 \mathrm{~min}$ (arrowed); closed symbols are in the absence of $\mathrm{NaCl}$ addition.

the mouse DNA methylase (Adams et al., 1992) indicate that it can methylate the trinucleotide sequence (unmethylated or hemimethylated) at about $5 \%$ the rate of (poly dI-dC) $($ poly dI-dC), which is in agreement with results from Toth et al. (1990) and from Simon et al. (1978).

\section{Enzyme/DNA binding}

With $30 \mathrm{ng}$ of hemimethylated CNG target DNA per assay, the rate of transfer of methyl groups is proportional to the amount of enzyme in the assay up to $3 \mu \mathrm{g}$ of protein, and the presence of

\section{Table 2 Stabilization of the enzyme by substrate}

Enzyme $\left(2.5 \mu \mathrm{g}\right.$; fraction Q) was pre-incubated for $10 \mathrm{~min}$ at $35^{\circ} \mathrm{C}$ or on ice $\left(0^{\circ} \mathrm{C}\right)$, in the presence of substrate [1 $\mu \mathrm{g}$ of DNA and S-adenosylmethionine (AdoMet) at $9.2 \mu \mathrm{M}$ ] where indicated, in a volume of $25 \mu$ l. All tubes were then incubated in a standard assay at $30^{\circ} \mathrm{C}$ for $2 \mathrm{~h}$ and methylase activity was determined. Results (from one of two similar experiments) are expressed as c.p.m. per assay and are averages of duplicate assays.

\begin{tabular}{|c|c|c|c|c|}
\hline \multicolumn{2}{|l|}{$\begin{array}{l}\text { Pre-incubation } \\
\text { reaction mix }\end{array}$} & \multicolumn{2}{|c|}{$\begin{array}{l}\text { Methylase activity } \\
\text { (c.p.m. per assay) }\end{array}$} & \multirow[b]{2}{*}{ Inhibition (\%) } \\
\hline$(\mathrm{CAG} / \mathrm{MTG})_{7}$ & AdoMet & $0^{\circ} \mathrm{C}$ & $35^{\circ} \mathrm{C}$ & \\
\hline- & - & 2800 & 900 & 68 \\
\hline+ & - & 2500 & 1200 & 52 \\
\hline+ & + & 2900 & 2500 & 14 \\
\hline- & + & 3700 & 900 & 76 \\
\hline
\end{tabular}
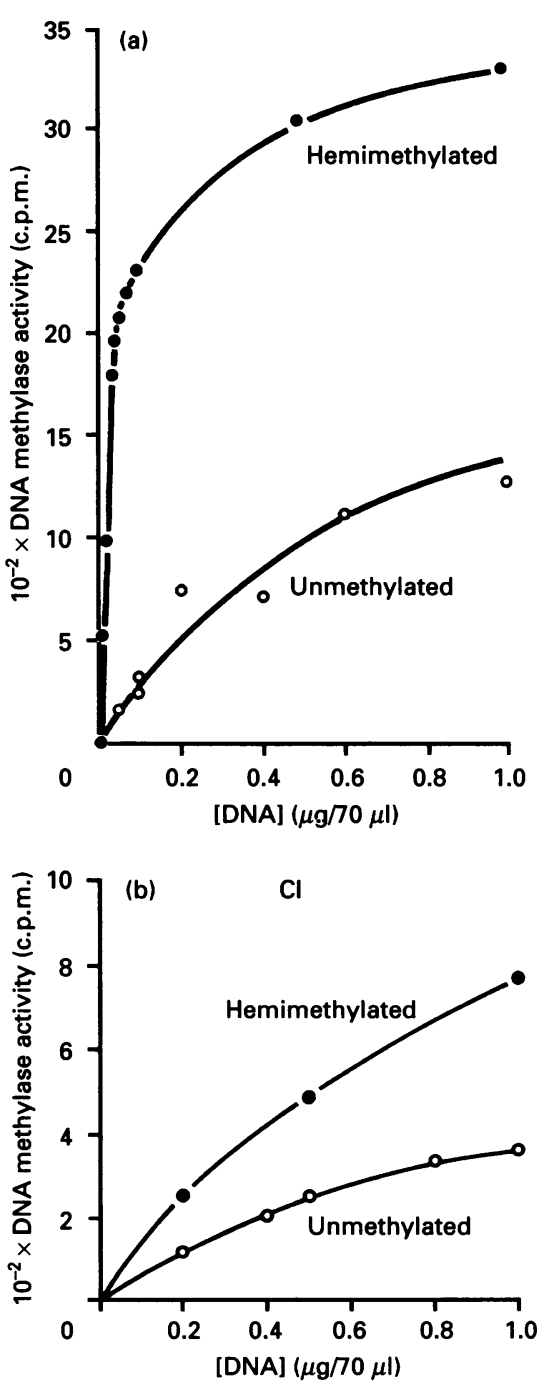

Figure 6 DNA concentration curves

The amount of DNA indicated was incubated for $2 \mathrm{~h}$ at $30^{\circ} \mathrm{C}$ in an incubation of $70 \mu \mathrm{l}$, with $5 \mu \mathrm{g}$ of protein from fraction $\mathrm{E} 1$, as described in the Experimental section. (a) Refers to the trinucleotide target DNA molecules $\mathrm{d}(\mathrm{CAG} / \mathrm{CTG})_{7}(\mathrm{O})$ and $\mathrm{d}(\mathrm{CAG} / \mathrm{MTG})_{7}(\mathbf{O})$, (b) to the dinucleotide target DNA molecules (poly $\mathrm{dl}-\mathrm{dC}) \cdot($ poly $\mathrm{dl}-\mathrm{dC})(\mathrm{O})$ and $($ poly $\mathrm{dl}-\mathrm{dC} / \mathrm{dM}) \cdot($ poly $\mathrm{dl}-\mathrm{dC} / \mathrm{dM})(\mathbf{O})$ 
Table 3 Kinetic values for various DNA substrates

\begin{tabular}{lcc}
\hline Substrate & $\begin{array}{l}K_{\mathrm{m}} \\
(\mu \mathrm{g} / \mathrm{ml})\end{array}$ & $\begin{array}{l}V_{\max } \\
(\mathrm{pmol} / \mathrm{h} \text { per mg) }\end{array}$ \\
\hline$(\mathrm{CAG} / \mathrm{CTG})_{7}$ & 14.3 & 340 \\
$(\mathrm{CAG} / \mathrm{MTG})_{7}$ & 0.71 & 340 \\
$(\mathrm{Cl} / \mathrm{Cl})_{n}$ & 13.0 & 72 \\
$(\mathrm{Cl} / \mathrm{MI})_{n}$ & 21.0 & 208 \\
Pea DNA & 20 & 26
\end{tabular}

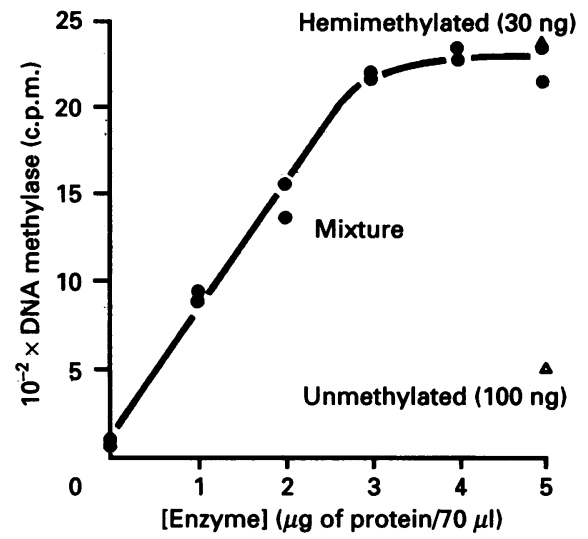

Figure 7 Enzyme concentration curve and effect of compettitor DNA

The curve shows the effect of increasing amounts of enzyme protein in a standard assay of $70 \mu$ containing $30 \mathrm{ng}$ of $\mathrm{d}(\mathrm{CAG} / \mathrm{MTG})_{7}$ and $100 \mathrm{ng}$ of $\mathrm{d}(\mathrm{CAG} / \mathrm{CTG})_{7}(\mathrm{O})$. In addition, the incorporation with $30 \mathrm{ng}$ of hemimethylated DNA alone is shown $(\boldsymbol{\Delta})$ and that with $100 \mathrm{ng}$ of unmethylated DNA alone $(\triangle)$.

$100 \mathrm{ng}$ of unmethylated CNG target DNA does not compete (Figure 7). This confirms the conclusion that the pea DNA methylase will preferentially bind to, and methylate, hemimethylated CNG target DNA in the presence of unmethylated sequences.

We have previously reported (Yesufu et al., 1991) that the pea DNA methylase rapidly forms a salt-resistant complex with pea DNA. This DNA will contain a variety of substrate sites including unmethylated and hemimethylated di- and trinucleotide target sequences. Figure 5 shows that the pea enzyme rapidly forms a stable, salt-resistant complex with the hemimethylated trinucleotide target sequence, but not with the unmethylated sequence, which stops accepting methyl groups almost immediately on addition of $\mathrm{NaCl}$. With the dinucleotide target sequences, the reaction continues for a limited time after the addition of $\mathrm{NaCl}$, but ceases after 60 min with the unmethylated sequence and after $90 \mathrm{~min}$ with the hemimethylated sequence. These times reflect the length of the substrate DNA, i.e. $21 \mathrm{bp}$ for $(\mathrm{CAG} / \mathrm{CTG})_{7} ; 100-500$ bp for (poly dI-dC) $($ poly dI-dC) and 500-2000 bp for (poly dI-dC/dM) $\cdot($ poly dI-dC/dM).

\section{DISCUSSION}

We have used synthetic oligonucleotides to study the substrate requirements of pea DNA methylase. To avoid loss of any species of enzyme, we have deliberately used a crude nuclear extract as a source of enzyme in many of the experiments reported in this paper. This extract shows multiple DNA cytosine methyltransferase activities that co-fractionate on gel filtration, although fractionation of different activities has been obtained using ion-exchange columns. We conclude therefore that the crude extract contains more than one enzymic activity, although whether this results from changes in conformation or from protein modification is not known. Several bands can be seen on SDS/PAGE of more purified fractions and attempts to reduce proteolysis by including further protease inhibitors (such as benzamidine) in the purification produced no consistent effect. Many of these bands cross-react with antibodies raised against an active-site peptide from the mouse DNA methylase and also with antibodies raised against a purified wheat DNA methylase, showing that there has been considerable conservation of sequence between species. However, one band at about $70 \mathrm{kDa}$ reacts exclusively with the antibody to the wheat DNA methylase and one might speculate that this protein is the CNG methylase. However, it is not possible at present to definitively identify particular bands with individual activities. Experiments in progress indicate that the enzyme can interact with the hemimethylated trinucleotide target sequence in the presence of a 1000 -fold excess of (poly dI-dC) $($ poly dI-dC), confirming the presence of two independent activities.

To follow methylation of a dinucleotide sequence we used the alternating copolymer (poly $\mathrm{dI}-\mathrm{dC}) \cdot($ poly $\mathrm{dI}-\mathrm{dC}$ ) as an unmethylated substrate. Unfortunately activity was extremely low with the hemimethylated analogues made by annealing synthetic oligonucleotides to poly $\mathrm{dI}-\mathrm{dC}$ and the reason for this is not known. Fortunately the hemimethylated dinucleotide target sequence made using DNA polymerase is a good substrate, with a $V_{\max }$ around 3-fold greater than the unmethylated analogue. As this substrate contains 3-fold more CI dinucleotides than MI dinucleotides, the actual rate of maintenance methylation is about 20 -fold greater than the rate of de novo methylation at this target sequence. Furthermore, the use of a limiting amount $(3 \mu \mathrm{g}$ per $\mathrm{ml}$ ) of a synthetic 22-mer duplex containing a single CG dinucleotide $8 \mathrm{bp}$ from one end gave a rate of reaction that was 9-fold greater when the duplex was hemimethylated (results not shown), showing that in a more normal sequence the enzyme shows greater activity with the hemimethylated substrate. This discrimination between de novo and maintenance methylation is not as great as that shown by the enzyme from rice cells (Giordano et al., 1991), which is also much smaller than the pea DNA methylase.

Synthetic repeating trinucleotide sequences in unmethylated and hemimethylated form provided substrates that enabled us to study the trinucleotide target sequence in isolation. We have not considered all possible CNG target sequences, as it is not possible to construct molecules containing CCG or the complementary CGG sequences without including CG dinucleotide sequences. A comparison of the rates of methylation of unmethylated duplexes with a simple repeating structure shows that the enzyme methylates the trinucleotide target sequence faster than the dinucleotide target sequence. This could explain why, in vivo, the fraction of the former that is methylated is considerably higher than that of the latter (Messeguer et al., 1991).

With limiting DNA, the ratio of maintenance to de novo activity observed varies from 10 to 30 and this could be a realistic value for the relative rates of maintenance and of de novo methylation that occur in vivo. As there are two possible sites for methylation in the unmethylated target duplex, this means that the rate of maintenance methylation per target cytosine is around 20-60-fold higher than the rate of de novo methylation. Clearly, a significant amount of de novo methylation could be occurring in vivo. 


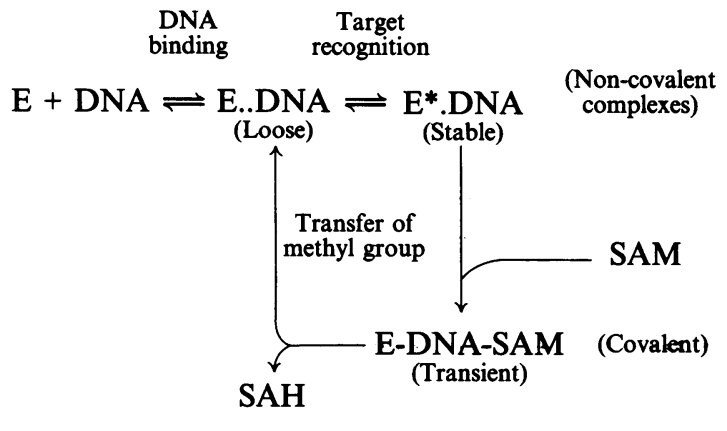

Figure 8 Interaction of pea DNA methylase with DNA containing CNG sequences

The enzyme interacts reversibly with any DNA to form a loose complex. This interaction is saltsensitive. When cytosines in CNG target sequences are present, the enzyme can interact with these to form a stable complex in which the enzyme may have undergone a conformational change $\left(E^{*}\right)$. This stable complex may be dissociated to regenerate the loose complex and the free enzyme and DNA or it may interact with S-adenosylmethionine (SAM) to form a transient, covalent complex. Transfer of a methyl group will liberate S-adenosylhomocysteine (SAH) and generate methylated DNA, still loosely associated with the enzyme.

It is probable that the enzyme can form a complex with any DNA, but it appears to interact with higher affinity with hemimethylated DNA, particularly that containing the trinucleotide target sequence. Complex formation. is dependent on the DNA concentration, as is shown in Figure 6, and low concentrations of hemimethylated trinucleotide target DNA are sufficient to saturate the enzyme. However, at saturating DNA concentrations, the rate of methyl-group transfer is similar with unmethylated or hemimethylated substrate, but is greater with trinucleotide target sequences than it is with dinucleotide target sequences (Table 3). The rate-limiting step must be the interaction of the enzyme/DNA complex with the second substrate, $S$ adenosylmethionine, and the consequent transfer of the methyl group.

It has been proposed that DNA methyltransferases form a covalent complex with their target sequence (Santi et al., 1984; Chen et al., 1991; Friedman and Ansari, 1992). The covalent complex probably forms as a result of the maturation of a series of intermediate complexes. Initially the enzyme will form a loose complex with any DNA and probably then will travel along the DNA until it recognizes a target site, at which point a stable, non-covalent complex will form. This is probably associated with a change in enzyme conformation. Only on interaction with $S$ adenosylmethionine will the covalent complex form. This complex could be broken either by the reversal of the formation reaction (probably an unlikely event) or on transfer of a methyl group, with the concomitant release of $S$-adenosylhomocysteine (Figure 8); that is, the covalent complex will form only transiently in the presence of a methyl donor, but may be stabilized in the presence of analogues such as $S$-adenosylhomocysteine or synefungin, which do not allow the transfer of a methyl group to occur. Such a situation has been shown to occur with several bacterial methyltransferases (for example, Bergerat and Guschlbauer, 1990; Dubey and Roberts, 1992).

With the pea enzyme, all the DNA substrates tested rapidly form salt-resistant complexes on mixing with the enzyme. However, these complexes dissociate after a time that is dependent on the length of the DNA. The exception is the complex formed with the hemimethylated trinucleotide target sequence, which is completely stable for $2 \mathrm{~h}$ or more (Figure 5; Yesufu et al., 1991). Why are lower concentrations of hemimethylated trinucleotide target DNA sufficient to saturate the enzyme and form a stable, salt-resistant complex? Either the stable complex is formed more readily with this DNA or the dissociation of the complex with the other DNAs is faster.

The results described lead us to propose the following series of events. The initial interaction of the DNA with the enzyme is inhibited by $0.1 \mathrm{M} \mathrm{NaCl}$. With most DNA there is a rapid equilibrium between unbound, loosely bound and tightly bound enzyme and DNA with the result that the reaction is rapidly inhibited by salt, which traps the reactants in an unbound form. With hemimethylated trinucleotide target DNA, the tightly bound DNA-enzyme complex is more stable and less likely to dissociate; the concentration of free reactants is, therefore, very low and the continued reaction is not sensitive to salt inhibition. This will have the effect, in vivo, of efficiently maintaining the level of CNG methylation, while the pattern of CG methylation may be more susceptible to disruption, either by chance or by the presence of competing proteins. A similar increased stability of the complex between DNA methylase and hemimethylated DNA is found for the mouse enzyme (A. Reale, H. P. Saluz, R. L. P. Adams, J. P. Jost and R. Strom, unpublished work).

We thank the SERC for a grant to support C.E.H. and this work, the British Commonwealth for support of S.P. and Professor Houslay and the University of Glasgow for the provision of facilities. We also thank Harmut Follmann for the antiserum to the wheat DNA methyltransferase and Tim Bestor for information concerning the sequence of the mouse methyltransferase CDNA.

\section{REFERENCES}

Adams, R. L. P. (1990) Biochem. J. 265, 309-320

Adams, R. L. P. and Burdon, R. H. (1985) Molecular Biology of DNA Methylation, Springer Verlag, New. York

Adams, R. L. P., McKay, E. L., Craig, L. M. and Burdon, R. H. (1979) Biochim. Biophys. Acta 561, 345-357

Adams, R. L. P., Hill, J., McGarvey, M. and Rinaldi, A. (1989) Cell Biophys. 15, 113-126

Adams, R. L. P., Lindsay, H., Reale, A., Seivright, C., Kass, S., Cummings, M. and Houlston, C. (1992) in DNA Methylation: Molecular Biology and Biological Significance (Jost, J.-P. and Saluz, H. P., eds.), pp. 120-144, Birkhäuser Verłag, Switzerland Banks, J. A. and Federoff, N. (1989) Dev. Genet. (N.Y.) 10, 425-437

Bergerat, A. and Guschlbauer, W. (1990) Nucleic Acids Res. 18, 4369-4375

Boyes, J. and Bird, A. (1991) Cell 64, 1123-1134

Chen, L., MacMillan, A. M., Chang, W., Ezaz-Nikpay, K., Lane, W. S. and Verdine, G. L. (1991) Biochemistry 30, 11018-11025

Comb, M. and Goodman, H. M. (1990) Nucleic Acids Res. 18, 3975-3982

Dobrzanski, P., Hoeveler, A. and Doerfler, W. (1988) J. Virol. 62, 3941-3946

Dubey, A. K. and Roberts, R. J. (1992) Nucleic Acids Res. 20, 3167-3173

Friedman, S. and Ansari, N. (1992) Nucleic Acids Res. 20, 3241-3248

Giordano, M., Mattachini, M. E., Cella, R. and Pedrali-Noy, G. (1991) Biochem. Biophys. Res. Commun. 177, 711-719

Gruenbaum, Y., Naveh-Many, T., Cedar, H. and Razin, A. (1981) Nature (London) 292, $860-862$

Hélène, C. and Toulmé, J.-J. (1990) Biochim. Biophys. Acta 1049, 99-125

Hershkovitz, M., Gruenbaum, Y., Renbaum, P., Razin, A. and Loyter, A. (1990) Gene 94, 189-193

Iguchi-Ariga, S. M. M. and Schaffner, W. (1989) Genes Dev. 3, 612-619

Kadonaga, J. T. and Tjian, R. (1986) Proc. Natl. Acad. Sci. U.S.A. 83, 5889-5893

Lewis, J. D., Meehan, R. R., Henzel, W. J., Maurer-Fogy, I., Jeppesen, P., Klein, F. and Bird, A. (1992) Cell 69, 905-914

Matzke, M. A. and Matzke, A. J. M. (1990) Dev. Genet. (N.Y.) 11, 214-223

Meehan, R. R., Lewis, J. D., McKay, S., Kleiner, E. L. and Bird, A. P. (1989) Cell 58, 499-507

Messeguer, R., Ganal, M. W., Steffens, J. C. and Tanksley, S. D. (1991) Plant Mol. Biol. 16, $753-770$

Pfeifer, G. P. and Drahovsky, D. (1986) FEBS Lett. 207, 75-78

Santi, D. V., Norment, A. and Garrett, C. E. (1984) Proc. Natl. Acad. Sci. U.S.A. 81 6993-6997

Simon, D., Grunert, F. V., Acken, U., Döring, H. P. and Kröger, H. (1978) Nucleic Acids Res. 5, 2153-2167

Smith, S. S., Kan, J. L. C., Baker, D. J., Kaplan, B. E. and Dembek, P. (1991) J. Mol. Biol. 217, 39-51

Toth, M., Müller, U. and Doerfler, W. (1990) J. Mol. Biol. 214, 673-683 
Van Lier, J. J. C., Smits, M. T. and Buck, H. M. (1983) Eur. J. Biochem. 132, 55-62 Vardimon, L. and Rich, A. (1984) Proc. Natl. Acad. Sci. U.S.A. 81, 3268-3272 Watt, F. and Molloy, P. L. (1988) Genes Dev. 2, 1136-1143

Weber, H., Ziechmann, C. and Graessmann, A. (1990) EMBO J. 9, 4409-4415
Yesufu, H. M. I., Hanley, A., Rinaldi, A. and Adams, R. L. P. (1991) Biochem. J. 273, $469-475$

Zhang, D., Ehrlich, K. C., Supakar, P. C. and Ehrlich, M. (1989) Mol. Cell. Biol. 9, 1351-1356

Received 23 November 1992/26 January 1993; accepted 3 February 1993 